\title{
Raising awareness of intertextuality in order to develop ESL reading and writing skills: an account of a successful lesson plan
}

\author{
Thais Regina Santos Borges \\ PUC-Rio
}

\section{Resumo}

Este artigo descreve um plano de aula de língua inglesa desenhado para aumentar a conscientização de alunos quanto à intertextualidade presente em textos escritos. Como o material trabalhado em classe geralmente dita os tópicos a serem desenvolvidos pelos alunos em suas redações, quando o livro propôs um debate sobre os prós e contras da medicina alternativa e o conteúdo programático previa a produção de uma dissertação, surgiu uma boa oportunidade para se trabalhar os níveis de intertextualidade no discurso escrito, como sugerido por Bazerman (1997). Assim, o objetivo da aula foi proporcionar aos alunos algum input proveniente de um poema satírico, para que juntamente com o input do livro didático e seu conhecimento anterior sobre o tema, os alunos pudessem se conscientizar dos aspectos de intertextualidade no entendimento do discurso escrito, como leitores e como escritores, para que viessem a se sentir mais confiantes ao escrever na língua inglesa.

Palavras-chaves: plano de aula - língua inglesa - produção escrita - discurso escrito - intertextualidade

\begin{abstract}
This article describes an ESL lesson plan designed to raise students' awareness of intertextuality in written texts. As the material worked in class usually dictates the topics to be developed in students' writing assignments, the moment the book proposed a debate on the pros and cons of Alternative Medicine and the syllabus included students' production of an essay, an opportunity arose to work with the levels of intertextuality in written discourse as suggested by Bazerman (1997). Along these lines, the aim of the lesson was to provide students with some input material (a satirical poem) as well as their course book input, so they could connect them with their previous knowledge on the topic, and thus become more aware of the role intertextuality plays when readers and writers make sense of written discourse, and ultimately feel more confident when writing in ESL.
\end{abstract}

Keywords: ESL lesson plan - writing assignment - written discourse intertextuality

\section{INTRODUCTION}

Developing students' reading and writing skills is not only a goal but also a great challenge in the ESL classroom. The reality is most teachers are not allowed to choose the 
syllabus they would like to cover, and extra input tends to be wrongly seen as secondary, which often leaves students adrift when it is time to do their own writing. Having said that, there are ways to mitigate these problems and one of them will be dealt with in this article. The understanding of Bazerman's concept of intertextuality is a means to encourage students to reflect upon what they read and write, as well as inspire teachers to wisely resort to extra input that will contribute to students' sea of texts (BAZERMAN, 2004). In other words, raising awareness of intertextuality will allow students to improve their reading skills as well as improve their written production.

\section{THEORETICAL FRAMEWORK}

\section{Genres}

As teachers, whenever we decide to work with reading/writing skills, we tend to think about genres, not only because they exist and we will come across many of them in our regular lives, but also because they facilitate learning of skills and parameters that will help our students perform their tasks better.

Many scholars have defined genres in different ways. John Swales (1990, p.45) defined genre as "a class of communicative events" which becomes genre due to "some shared set of communicative purposes" (ibid, p.46). He also mentions the rationale behind genres, saying it "shapes the schematic structure of discourse and influences and constrains choice of content and style" (ibid, p.58). Bhatia (2004, p.23), who also believes in the imposition of constraints, focuses on the conventions and "the use of lexico-grammatical devices as well as discoursal resources".

The definition I used to guide my choices for this class is Bazerman's (1997, p.19), because he goes a bit beyond that, in my view, stating that "[g]enres are not just forms. Genres are forms of life, ways of being. They are frames for social action. They are environments for learning. They are locations within which meaning is constructed”.

Exactly because genres can be such a tool for making meanings, it is important to be able to recognize their features and know which of these features to use in each circumstance. Different genres can be connected, according to the Bazerman's (1997) notion of genre systems, therefore, not only due to the language devices used in them, but because of the content, the construction of meaning and the social action intended. Besides, this idea of genres as forms of life definitely stands out, especially when accounting for the organic aspect of evolution - and/or death! - of genres. 
Along these lines, the beat poem chosen for this class (see Appendix) fits perfectly with the writing assignment asked from the students: an essay, showing pros and cons of the topic raised by the poem itself. It has the right mixture of well-written passages with an interesting choice of lexico-grammatical devices as well as a baggage of reasonable arguments.

\section{Intertextuality}

Regarding aspects of intertextuality, the lesson plan was based on Bazerman's idea that "we create our texts out of the sea of texts that surround us, the sea of language we live in" (BAZERMAN, 2004, p.83). Following the lesson plan, students learned about a point of view on the subject matter of the essay they would later have to write, so they were asked to analyze the connections between the sea of texts surrounding the text they had in hands.

In order to have a deeper understanding of the meaning these many texts convey, I resorted to Gee's (1999, p.7) approach to discourse, focusing on "little d" discourse and "big D" Discourses. The former concerns "how language is used 'on site' to enact activities and identities" (GEE, 1999, p.7) and the latter, the

\footnotetext{
different ways in which we humans integrate language with non-language 'stuff', such as different ways of thinking, acting, interacting, valuing, feeling, believing, and using symbols, tools, and objects in the right places and at the right times so as to enact and recognize different identities and activities (ibid, p.7).
}

Students were, therefore, prepared to take into consideration two different but complementary views on how to deal with texts.

Bearing this in mind, students had to look for traits of intertextuality in the reading sample, making use of a simplified version of Bazerman's (2004, p.86) "six levels of intertextuality", as indicated in this article.

Based on the proposition that there are "explicit and implicit relations" (ibid) not only "between a text and its prior or contemporary texts" but also between a text and "potential future texts" (ibid) and the reading of the essays handed by students, they seem to have truly benefited from the exposure to the sample material before they actually performed the writing task.

In order to help raise students' awareness to the role of intertextuality, without going into much detail, I asked students to look for examples in the text which showed any of the 
"six levels of intertextuality" mentioned by Bazerman (ibid) so they could frame their analysis.

Along these lines, according to Bazerman (2004, p.86-88) these are the six levels, which consist of six "techniques of intertextual representation" depicted in a text to represent other voices, as follows:

1) "a source of meanings to be used at face value", which maintains the author's "control over exactly which words will be quoted, the points at which the quote will be snipped, and the context it will be used in";

2) "explicit social drama", which consists of bringing controversial views of the same situation "side by side in a direct confrontation";

3) "background, support and contrast", which summarizes the explicit mentioning of other statements as back up to an assertion, such as "figures from an encyclopedia, (...) newspaper reports to confirm events, or (...) quotations from a work of literature to support an analysis

4) "beliefs, issues, ideas, statements generally circulated", which concerns the less explicit use of material that could be either from "a specific source" or understood "as common knowledge";

5) "recognizable kinds of language, phrasing and genres", which is language familiar to the reader, as "every text evokes particular social worlds where such language and language forms are used, usually to identify that text as part of those worlds"

6) "resources of language", which encompasses the use of language devices which rely on the resources available "without calling particular attention to the intertext", since "every text, all the time, relies on the available language of the period, and is part of the cultural world of the times"

By going through the levels in the poem, students were trying to find when and how the text "invokes another text and relies on the other text as a conscious resource" (BAZERMAN, 2004, p.86). Under this umbrella, even though we do not actually deal with academic texts, students in general benefitted from the exercise of training their eyes to find evidence of intertextuality. 


\section{Interaction}

The concept of the "text as a site for interaction" (HOEY, 2001, p.11) is also an important one because of its implications in the classroom. The idea that students formulate a hypothesis as they go on reading (HOEY, 2001) helps learners create expectations that will or will not be fulfilled in the course of reading, allowing for interpretation and conclusion on the part of the reader (ibid). Developing these "hypothesis-forming skills" (ibid, p.32), appropriately, will ensure better understanding of written texts and surely avoid the treatment of reading as "an exercise to language practice only" (ibid, p.31).

Bearing this in mind, when dealing with the reading material in class, it is crucial that we engage students in the process of "hypothesis-forming" so they can start to develop their own idea of what is about to be discussed (before actually reading it) and also what is in fact discussed (while reading). The idea that we could use this concept and develop it into "guesswork" (ibid, p.32) in order to infer meaning and other ideas beyond the text itself really called my attention and played an important part when preparing the first part of my lesson plan.

\section{CONTEXTUALIZATION AND PROCEDURES}

As mentioned before, the aim of the class represented here by this lesson plan was to help students improve their reading and writing skills regarding fluency by raising their awareness of features of intertextuality (BAZERMAN, 2004) when writing an essay.

Students were shown a poem/rap first in the form of a written text which they read looking for hints of intertextuality (both within the same text and beyond it) and then they watched it being recited by the author. In the poem, the author positions himself against Alternative Medicine, which was also the topic suggested for their essay. This topic had been discussed in class over the month before within the syllabus and the course book itself, when students were offered other opinions on the issue.

The pace of the poem helps create this atmosphere of a debate and allows for students to infer a lot of meaning and conclusions, crucial to the writing of their own essays. Although there is use of foul language at times, that does not compromise the text and it seems to be very pertinent to creating atmosphere - it could also be seen as a good chance to point out the appropriateness of this use and the importance of understanding how register (tenor, mode and field) influences our choices. Having said that, I only used the beginning of the poem which 
does not show any use of bad language.

By the end of the class students had been introduced to the idea that "no text is an island" (WIDDOWSON, 1993, in JONES, 1997). They were also encouraged to draw some input from the texts they had read, which included the poem/rap, the reading material from the course book as well as those outside the limits of the classroom. Students were then invited to provide their own input based on their previous knowledge.

\section{Students}

This class was a Master 2 class held at Cultura Inglesa, with advanced level students, which means students were at level $\mathrm{C} 1$ according to the parameters of CEFR, the Common European Framework of Reference for Languages: Learning, Teaching, and Assessment. Their age varied between 16 and 18 and they had been studying English for between 4 to 8 years. They were 10 in total but not all of them attended class frequently. Only seven of them - three boys and four girls - were usually present in class.

At this level in that English Institute, this is their last step before they graduate, and so students are exposed to the idea of fluency as a rather broader concept: as a feature of different skills, not just speaking. Although they are more familiar with the meaning of Speaking Fluency, they start to draw parallels with writing and reading as well.

A good example of how students in that Master 2 group grasped the idea of fluency was given when one student came up with the idea of "not tripping over" as a metaphor for being fluent, which was then translated by another one into "a limited number or the lack of hesitations when speaking", and eventually "being able to make connections and interpretations when reading" and "conveying your message effectively when writing". The concept was then developed over the whole semester and some techniques and strategies were shown to them so as to make sure they were put on the right track to develop fluency in all their ESL skills in a more complete and effective way.

\section{Course book Input}

The course book adopted with this class was Cambridge's English Unlimited Advanced Course, by Adrian Doff and Ben Goldstein. The classes started in unit 7, which deals almost exclusively with the topic of "Health", developed under the umbrella of "Health and Treatment", more specifically the notions of "placebo/nocebo", "witch doctors" and "different types of issues (health issues; economic, political, etc., issues)". 
At the moment this lesson plan was developed, the group was right in the middle of the unit and, to further the debate, the course book presented an article on Alternative Medicine in the Self-Study Pack. This article was meant to work as inspiration and input for Students' own written production, as described in the syllabus of their course. As intended, they read the article and then we worked on meaning and interpretation so as to shed light on the topic in question.

\section{Poem/Rap - Extra Input}

The reading material chosen for the lesson was a poem written by Tim Minchin, who defines himself as "an Australian musician, composer, songwriter, actor, comedian and writer" (TIM MINCHIN's official website). He produces and stages musical comedies in which he touches various delicate topics such as "environmentalism, rationalism, prejudice(ism), logical fallacies(ism)", as he jokingly describes on his website. His pieces are usually very thought-provoking and this specific piece named "Storm" is specially known for that.

"Storm" is a 9-minute beat poem that describes a dinner-party encounter between Tim Minchin, a skeptical atheist who believes in science and knowledge, and "Storm", a young woman who believes in psychic power and faith (see Appendix). They start a debate halfway through which Tim Minchin starts ranting and raving about the difference between "trust in science" and "belief in supernatural powers". Part of their argument is specifically about Medicine X Alternative Medicine, which was the basis for our work. Since the poem is very long, only $3 \mathrm{~min}$ and $40 \mathrm{~s}$ were enough to serve the purpose of the class.

Working with the poem proved rather useful in class. Not only was it used to exemplify the six levels of intertextuality (BAZERMAN, 2004), but it also conversed with students' own work later on when they wrote their own essays, indicating a very interesting approach based on their awareness to the intertextuality.

Besides that, "Storm" is recited very vehemently in a live show by Tim Minchin, which adds prosodic features to the reading, helping them understand better how the author truly feels about the subject matter. The poem has also been made into an animated film which provided an extra possibility to explore the poem through another medium, captivating students' attention and having them think about the text with more depth and substance.

\section{LESSON PLAN}

\section{Overview}


The first part of the class focused on defining some elements of intertextuality. Then, a debate concerning levels of intertextuality was held and finally students were introduced to their homework task - writing an essay on pros and cons of Alternative Medicine.

In this class specifically, students were supposed to produce an essay, which is a genre they were already quite familiar with. As they had been working on the topic for quite some time, students had to write their essay using some of the vocabulary they had seen over the past month.

\section{The lesson}

Students received the poem (see attachment) and they had to read the first three verses - until "Or a window on the second floor") quickly answering the following questions in pairs:

\section{What's going on?}

\section{How many people are there? Where are they? What are they doing? What do you know about Storm?}

Then, they had to listen to Minchin reciting the poem while they read it. I stopped the poem at $1 \mathrm{~min} 34 \mathrm{~s}$, covering only what they would read, before the characters in the poem started arguing about Alternative Medicine so they would then answer the next two questions:

\section{What do you think is Tim's opinion on Alternative Medicine?}

\section{And Storm's?}

\section{Why do you think so?}

At this moment, I asked them how they knew each person's opinion. Then I explained that when we infer conclusions and connect ideas between the text we read and what we know, learn or remember, we somehow resort to intertextuality as well as our previous knowledge, which is an important resource to make us better readers and writers. Then, I proposed we worked on this and asked students to research the poem for some expressions/passages that show intertextuality.

In order to make it a little less confusing and more objective for students, they were presented very lightly with Bazerman's concepts of intertextuality (BAZERMAN, 2004). In fact, they were invited to find examples in the text which notably depicted the levels explained by Bazerman without actually mentioning the levels themselves. Bearing this in 
mind, they had to find the following:

1) expressions/passages they clearly recognized as coming from somewhere else, mentioning the original)

2) expressions/passages which showed opposing arguments (pinpoint both sides) or social drama

3) figures, facts, citations or quotes used for reasoning

4) expressions/passages which depicted underlying beliefs, issues or ideas

5) expressions/passages which reminded them of a certain social world/group/identity

6) idiomatic expressions, collocations and other expressions/phrases which required familiarity on the part of the reader

That meant that level 1 "a source of meanings to be used at face value" (BAZERMAN, 2004, p.87) became "expressions/passages they clearly recognize as coming from somewhere else, mentioning the original", level 2 "explicit social drama" (ibid) became "expressions/passages which show opposing arguments (pinpoint both sides)", level 3 "background, support and contrast" (ibid) became "figures, facts, citations or quotes used for reasoning", level 4 "beliefs, issues, ideas, statements generally circulated" (ibid) became “expressions/passages which depict underlying beliefs, issues or ideas", level 5 "recognizable kinds of language, phrasing and genres" (ibid) became "expressions/passages which remind them of a certain social world/group/identity" and finally level 6 "resources of language" (BAZERMAN, 2004, p.88) became "idiomatic expressions, collocations and other expressions/phrases which require familiarity on the part of the reader".

Students were then set in pairs in order to find and highlight the parts of the poem in which they identified each level above. After some time working together, students listened to the whole bit of the poem (until minute 3:42) and were asked to compare their findings with another pair (see Appendix for answers).

After comparing their findings they were put in groups to work on raising awareness to the presence of these elements of intertextuality and how they could resort to them when writing. So, while comparing their findings, they should answer the following questions, in groups:

How did you recognize the elements - did you use the text itself, other texts or your own ideas? 


\section{Was any level not noticeable in the poem?}

\section{Which expressions/passages/elements were easier to spot? Why do you think so?}

Then, after getting some feedback from the whole group, they were referred to the Bazerman's levels and invited to share their views on how useful they can be when writing, by answering the following questions:

\section{Do you often use similar resources when writing? Which ones? \\ Which ones do you find most useful in essays? Why? \\ Are there any you would not use in an essay? Why not?}

By making evident the influence of other texts in what they read and then having them think about their own writing, the aim of the discussion was to have them think about intertextuality and how it plays a part in developing both skills, as they end up showing traits of what they have been exposed to in other texts when they perform any related task.

To wrap up, they were shown the animation video (only the part that covers what they had read) and then, in pairs again, they said who they agreed with the most, giving their opinions about the topic while using some of the resources they had pinpointed before.

As homework, students were asked to produce an essay on the topic, focusing on intertextuality features as they did the task, which meant they should resort to the poem, the course book article, the Self-Study Pack article and any other text they found connected to the theme to be developed by them.

\section{FINAL CONSIDERATIONS}

The most interesting thing about working with different genres is the possibility of connecting different texts through context and raise awareness on the part of the students so they realize the importance of understanding that a text does not exist as an isolated unit in itself (HOEY, 2001). Also, intertextuality and interaction play a big part in creating meaning as the reader infers and hypothesizes on the go. It is essential to show learners the many possibilities a text allows and to equip them with tools which will enrich their reading and writing experience. Especially when dealing with writing tasks, it is crucial to prepare students to learn how to get their message across while keeping in mind that "no text is an island" (WIDDOWSON, 1993, in JONES, 1997). By including aspects that go beyond the 
text in the teaching of ESL writing, we definitely empower students by raising their awareness to the many dimensions of a text so they can become better readers and writers. In this specific class, students were introduced to the concepts of intertextuality and some traits already showed in the essays they did as homework. Having them understand and deal with the notion of intertextuality also proved rather fruitful as students used the concepts throughout the rest of the course for developing their reading and writing skills.

\section{REFERENCES}

BAZERMAN, C. The life of genre, the life in the classroom. In: Bishop, W.; Ostrom, H. (eds.) Genre and writing: issues, arguments, alternatives. Portsmouth, NH: Heinemann. 1997.

BAZERMAN, C. Intertextuality: How texts rely on other texts. In: Bazerman, C.; Prior, P. A. (eds.) What writing does and how it does it. Mahwah, NJ: Lawrence Eribaum Associates. 2004.

BHATIA, V. K. Worlds of written discourse: a genre-based view. London: Continuum. 2004.

HOEY, M. Textual Interaction: An Introduction to Written Discourse. Analysis. London: Routledge. 2001.

GEE, J. P. An introduction to discourse analysis: theory and method. New York: Routledge. 1999.

JOHNS, Ann M. Text, role, and context: Developing academic literacies. Cambridge: Cambridge University Press. 1997.

MINCHIN, Tim. $\quad$ Storm. $\quad \underline{\text { http://www.stormmovie.net/ }}$ and http://www.lyricsmania.com/storm_lyrics tim_minchin.html

SWALES, J. M. Genre analysis: English in academic and research settings. Cambridge: Cambridge University Press. 1990.

\section{AAUTORA}

Thais Regina Santos Borges é especialista em Língua Inglesa pela PUC-RJ e aluna do curso de Mestrado em Estudos da Linguagem da PUC-RJ. Trabalha como professora de inglês e coordenadora da Cultura Inglesa - Filial Botafogo e presta consultoria acadêmica para o departamento de Gerência de Cursos da Cultura Inglesa SA. Tem experiência na área ensino de língua inglesa como língua estrangeira (EFL teaching), análise crítica de discurso, 
ideologia de gênero, uso do humor na sala de aula de inglês como língua estrangeira. A autora é graduada em Arquitetura e Urbanismo pela UFJF. E-mail: thaisrsborges@gmail.com

\section{APPENDIX}

The Poem - depicting the levels as indicated by Bazerman (1997)

Observation 1: level 1 has not been observed in the poem.

Observation 2: In order to organize the levels, the poem has been marked with underlining and bold markers (when highlighting expressions/single words) as well as \{\} signs (when the level refers to a longer stretch of text).

Storm - by Tim Minchin (3min42)

$\{\underline{\text { Inner North London, top floor flat } \rightarrow \text { level 6: }}$ a wealthy neighborhood

All white walls, white carpet, white cat,

\section{Rice Paper partitions}

\section{Modern art and ambition}

The host's a physician $\rightarrow$ level 5: group identity

Lovely bloke, has his own practice $\rightarrow$ \{level 4: implying wealth\}

His girlfriend's an actress $\rightarrow$ level 5: group identity

An old mate from home

And they're always great fun.

So to dinner we've come.

The 5th guest is an unknown,

The hosts have just thrown

Us together for a favor

Because this girl's just arrived from Australia

And has moved to North London

And she's the sister of someone

Or has some connection.

As we make introductions

I'm struck by her beauty 
She's irrefutably fair

With dark eyes and dark hair

But as she sits

I admit \{ I'm a little bit wary $\rightarrow$ \{level 4: implying disapproval of fairy tattoos/star signs\}

because I notice the tip of the wing of a fairy

Tattooed on that popular area

Just above the derrière

And when she says "I'm Sagittarian" $\} \rightarrow$ level 6: star sign

$\{$ I confess a pigeonhole starts to form

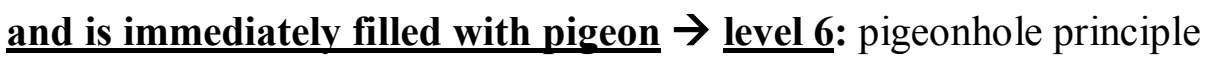

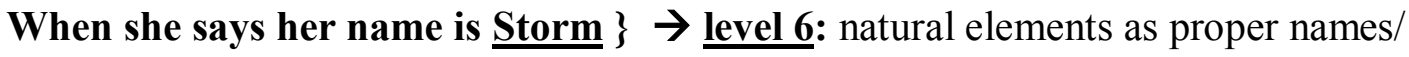

hippie culture $\rightarrow$ level 5: group identity (hippies) $\rightarrow$ \{level 4: implying he dislikes hippie culture $\}$

Chatter is initially bright and light hearted

But it's not long before Storm gets started:

You can't know anything,

Knowledge is merely opinion"

She opines, over her Cabernet Sauvignon $\rightarrow$ level 6: a type of red wine

$\mathrm{V}$ is a vis

Some $\{\underline{\text { unhappily }} \rightarrow$ level 6: unlike the hippie culture $\rightarrow$ \{level 4: implying dislike $\}$ empirical comment by me

Not a good start" I think

We're only on pre-dinner drinks

And across the room, my wife

Widens her eyes

Silently begs me, Be Nice

A matrimonial warning

Not worth ignoring

So I resist the urge to ask Storm

$\{$ Whether knowledge is so loose-weave

Of a morning 


\section{When deciding whether to leave}

\section{Her apartment by the front door}

Or a window on the second floor $\} \rightarrow$ \{level 4: implying scientific stance level 6: gravity\}

The food is delicious and Storm,

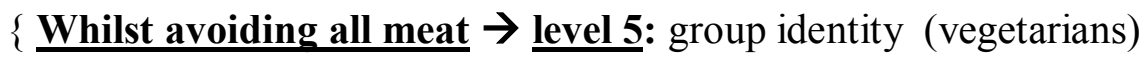

Happily sits and eats

While the good doctor, slightly pissedly

Holds court on some anachronistic aspect of medical history $\} \rightarrow\{$ level 2:

opposing stances/social drama

When Storm suddenly she insists

"But the human body is a mystery!

Science just falls in a hole

when it tries to explain the nature of the soul."

My hostess throws me a glance

She, like my wife, knows there's a chance

That I'll be off on one of my rants

But my lips are sealed $\rightarrow$ level 6: in silence

I just want to enjoy my meal

And although Storm is starting to get my goat $\rightarrow$ level 6: to annoy someone

I have no intention of rocking the boat $\rightarrow$ level 6: to ruin it

Although it's becoming a bit of a wrestle

Because - like her meteorological namesake $\rightarrow$ level 4: implying ridicule

Storm has no such concerns for our vessel:

\section{\{ "Pharmaceutical companies are the enemy}

They promote drug dependency

At the cost of the natural remedies

That are all our bodies need

They are immoral and driven by greed.

Why take drugs 
when herbs can solve it?

Why use chemicals

when homeopathic solvents

can resolve it?

It's time we all return-to-live

with natural medical alternatives. $\} \rightarrow$ \{level 2 : argumentation 1/social drama $\}$

And try as hard as I like;

a small crack appears

in my diplomacy-dike.

\{ "By definition", I begin

"Alternative Medicine", I continue

"Has either not been proved to work,

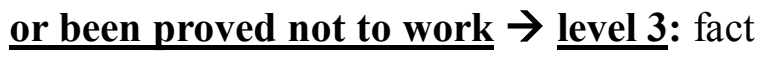

you know what they call "alternative medicine"

That's been proved to work?

Medicine." $\} \rightarrow$ \{level 2: argumentation 2/social drama

"So you don't believe

in ANY Natural remedies?

$\{$ “On the contrary actually:

Before we came to tea $\rightarrow$ level 6: dinner

I took a natural remedy

Derived from the bark of a willow tree

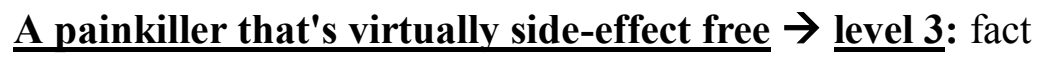

It's got a weird name,

Darling, what was it again?

Masprin?

Basprin?

Aspirin!

which I paid about a buck for

Down at my local drugstore" $\} \rightarrow$ \{level 2: argumentation 3 /social drama

(It continues - for full version check the website in the References) 